\title{
USING ELECTRICAL RESISTIVITY IMAGING TO CHARACTERIZE KARST HAZARDS IN SOUTHEASTERN MINNESOTA AGRICULTURAL SETTINGS
}

\author{
Toby Dogwiler \\ Missouri State University, Geography Geology and Planning, 901 S. National Ave., Springfield, MO 65897, \\ TDogwiler@MissouriState.edu
}

\section{Blake Lea}

Missouri State University, Geography Geology and Planning, 901 S. National Ave., Springfield, MO 65897

\begin{abstract}
Much of the Driftless Area of southeastern Minnesota is underlain by karstified carbonate bedrock. Land use in this karst terrain is dominated by agriculture, including row crop and dairy operations. The karst in this region is often mantled with up to $15 \mathrm{~m}$ of soil and unconsolidated sediments. As a result, underlying karst hazards such as incipient sinkholes are often hidden until they are suddenly revealed by the collapse of subsurface voids.
\end{abstract}

Regionally, the economics of the dairy industry is causing a trend toward the consolidation and expansion of existing operations. As concentrated animal feeding operations (CAFO) or feedlots expand, state and local agencies are charged with enforcing regulations designed to protect environmental and water resources in agricultural areas. One of the key challenges in reviewing and siting expanded dairies is identifying potential karst hazards, particularly where they might undermine manure storage facilities or where they occur on croplands where manure is applied. Uncertainty about the location of karst hazards relative to proposed feedlot facilities is one of the reasons that feedlot expansions in the Driftless Area are often controversial. Recently, the Minnesota Pollution Control Agency enacted strict guidelines that severely limit bedrock removal in order to facilitate the construction of manure storage containments. The purpose of this rule is to ensure that a minimum separation is maintained between intact bedrock and the containment liner to provide the opportunity for attenuation within the soil of contaminants that could potentially leak if the containment structure is compromised.
Electrical Resistivity Imaging (ERI) techniques have been employed to screen for karst hazards during the planning phase of feedlot expansions, and where present, to more accurately characterize the nature of the karst hazard. Because depth-to-bedrock is highly variable in the karst terrain of southeastern Minnesota, ERI has also been a useful tool to characterize this spatial variation under proposed manure containment sites. In this study, ERI was performed using a 56-channel AGI Supersting ${ }^{\mathrm{TM}}$ system with post-processing of the data in EarthImager ${ }^{\mathrm{TM}}$ software. Dipole-Dipole and Wenner electrical resistivity arrays have been the most useful for identifying karst hazards. Electrode spacing of 3 to 5 $\mathrm{m}$ has provided a good balance between depth-of-image and the spatial resolution necessary to locate and identify karst hazards. Soil boring data, which is typically collected during pre-construction site investigations, is critical to the interpretation of ERI data. Although individual sites vary, most surface materials in southeastern Minnesota have resistivities that fall within predictable ranges: 20-80 ohm-m for soils, 80-100 ohm-m for epikarst and weathered residuum, and $>100 \mathrm{ohm}-\mathrm{m}$ for bedrock. Karst voids in the subsurface typically display resistivities greater than $1000 \mathrm{ohm}-\mathrm{m}$, providing good contrast with the resistivities of the surrounding bedrock.

ERI has been an effective tool in identifying karst hazards in agricultural settings of southeastern Minnesota. In addition to improving pre-construction site assessments, ERI has also helped to reduce potential controversy surrounding the karst hazards of proposed projects by providing more certainty about the underlying geology. 
